Table 1. Respondent characteristics.

\begin{tabular}{|c|c|c|c|c|c|}
\hline & \multirow[t]{2}{*}{ Characteristics } & \multicolumn{2}{|c|}{ All } & \multicolumn{2}{|c|}{$\begin{array}{c}\text { Inflammatory } \\
\text { rheumatic disease } \\
\text { patients }\end{array}$} \\
\hline & & $(n=591)$ & $(\%)$ & $(n=453)$ & $(\%)$ \\
\hline & Female gender, $n(\%)$ & 353 & (59.7) & 286 & $(63.1)$ \\
\hline & $\begin{array}{l}\text { Age, median (IQR), } \\
\text { years }\end{array}$ & 59.0 & $(51.0-67.0)$ & 60.0 & $\begin{array}{r}(51.0- \\
67.5)\end{array}$ \\
\hline \multirow[t]{6}{*}{ Biologics } & Adalimumab & 220 & (37.2) & 164 & $(36.2)$ \\
\hline & Etanercept & 196 & (33.2) & 189 & $(41.7)$ \\
\hline & Infliximab & 43 & (7.3) & 8 & $(1.8)$ \\
\hline & Tocilizumab & 21 & (3.6) & 17 & (3.8) \\
\hline & Ustekinumab & 21 & (3.6) & 7 & (1.5) \\
\hline & Other & 90 & (15.2) & 68 & $(15.0)$ \\
\hline \multirow{5}{*}{$\begin{array}{l}\text { Combination } \\
\text { therapy }\end{array}$} & Methotrexate & 195 & (33.0) & 183 & $(40.4)$ \\
\hline & Corticosteroids & 65 & (11.0) & 51 & (11.3) \\
\hline & Thiopurines & 41 & (6.9) & 10 & $(2.2)$ \\
\hline & $\begin{array}{l}\text { No combination } \\
\text { therapy }\end{array}$ & 231 & (39.1) & 157 & $(34.7)$ \\
\hline & Other & 123 & (20.8) & 106 & (23.4) \\
\hline \multirow{4}{*}{$\begin{array}{l}\text { Indications for bio- } \\
\text { logic therapy }\end{array}$} & Rheumatoid arthritis & 277 & $(46.9)$ & 277 & $(61.1)$ \\
\hline & Psoriatic arthritis & 111 & (18.8) & 111 & $(24.5)$ \\
\hline & $\begin{array}{l}\text { Ankylosing spondylitis/ } \\
\text { axSpA }\end{array}$ & 83 & $(14.0)$ & 83 & (18.3) \\
\hline & Other & 159 & (26.9) & 17 & (3.8) \\
\hline
\end{tabular}

IQR: interquartile range; axSpA: axial spondyloarthritis.

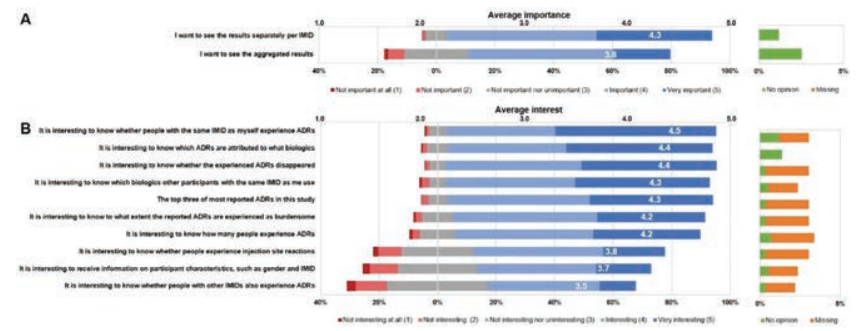

Figure 1. The preferences of patients on the communication of the reported adverse drug reaction information resulting from the Dutch Biologic Monitor.

Conclusion: Participants of the Dutch Biologic Monitor that use a biologic for their IMID prefer to receive ADR information tailored to their own biologic and IMID. Furthermore, they want to obtain insight in the course of ADRs. Therefore, we advocate to generate disease-specific information on ADRs for IMID patients. References:

[1] Kosse LJ, Jessurun NT, Hebing RCF, Huiskes VJB, Spijkers KM, van den Bemt BJF, et al. Patients with inflammatory rheumatic diseases: quality of self-reported medical information in a prospective cohort event monitoring system. Rheumatol. published on 30 Sept 2019. doi: 10.1093/rheumatology/ kez412.

Disclosure of Interests: Gerda Weits: None declared, Leanne Kosse: None declared, Harald Vonkeman: None declared, Phyllis Spuls Grant/research support from: Departmental independent research grant for TREAT NL registry LeoPharma December 2019; Contract support: I am involved in performing clinical trials with many pharmaceutical industries that manufacture drugs used for the treatment of e.g. psoriasis and atopic dermatitis for which we get financial compensation paid to the department/hospital, Consultant of: Consultancies in the past for Sanofi 111017 and AbbVie 041217 (unpaid), Bart van den Bemt Grant/research support from: UCB, Pfizer and Abbvie, Consultant of: Delivered consultancy work for UCB, Novartis and Pfizer, Speakers bureau: Pfizer, AbbVie, UCB, Biogen and Sandoz., Sander Tas: None declared, Frank Hoentjen Grant/research support from: Received grants from Dr Falk, Janssen-Cilag, and AbbVie., Consultant of: Served on advisory boards, or as speaker or consultant for AbbVie, Celgene, Janssen-Cilag, MSD, Takeda, Celltrion, Teva, Sandoz, and Dr Falk, Speakers bureau: Served on advisory boards, or as speaker or consultant for AbbVie, Celgene, Janssen-Cilag, MSD, Takeda, Celltrion, Teva, Sandoz, and Dr Falk, Michael Nurmohamed Grant/research support from: Not related to this research, Consultant of: Not related to this research, Speakers bureau: Not related to this research, Martijn van Doorn Grant/research support from: Unrestricted grants, advisory board, speaker fees and/or other (investigator) from Novartis, Abbvie, Janssen Cilag, Leopharma and Pfizer, Speakers bureau: Unrestricted grants, advisory board, speaker fees and/or other (investigator) from Novartis, Abbvie, Janssen Cilag, Leopharma and Pfizer, Eugène van Puijenbroek: None declared, Naomi Jessurun: None declared

DOI: 10.1136/annrheumdis-2020-eular.1841

\section{OP0269-HPR ASSOCIATION OF SARC-F PERFORMANCE WITH COMORBIDITIES, PHYSICAL DISABILITY AND LOWER ALBUMIN LEVELS IN SYSTEMIC SCLEROSIS PATIENTS}

L. Santos ${ }^{1,2}$, R. Cavalheiro Do Espírito Santo ${ }^{1,2}$, V. Hax ${ }^{1,2}$, R. Mendonça Da Silva Chakr ${ }^{1,2}$, R. Xavier ${ }^{1,2} .{ }^{1}$ Universidade Federal do Rio Grande do Sul UFRGS, Porto Alegre, Brazil; ${ }^{2}$ Hospital de Clínicas de Porto Alegre - HCPA, Division of Rheumatology, Porto Alegre, Brazil

Background: Systemic sclerosis (SSc) is a multisystem autoimmune disease of complex etiopathogeny, heterogeneous in its phenotypic expression and with a limited prognosis (1). The loss of muscle mass is a serious consequence of many chronic diseases and also is observed in SSc (2). This body composition alterations results in weakness, limitations and physical disability (3). SARC-F simple questionnaire, validated, is a key diagnostic feature for the fast assessment of geriatric syndromes associated with skeletal muscle wasting. However, there is no data about the SARC-F in SSc.

Objectives: To assess the association between the SARC-F questionnaire with clinical features in patients with systemic sclerosis (SSc).

Methods: Ninety-four patients diagnosed with systemic sclerosis were recruited and evaluated. Sarcopenia was assessed by the SARC-F questionnaire. Clinical features as disease duration time, comorbidities, body mass index (BMI), functional capacity by the Health Assessment Questionnaire (HAQ), inflammatory markers (C-reactive protein (CRP), erythrocyte sedimentation rate (ESR), creatine phosphokinase (CPK), hemoglobin, creatinin and albumin) were medical record. Frequency analysis, descriptive analysis and Pearson's correlation were performed. Statistical significance was considered as $p<0,05$.

Results: Of the 94 patients analyzed, most were women (87/94;92.6\%) with mean age of $60.5 \pm 10.3$ years, median disease duration time of 11.2 (7.5-18.9) and median number of comorbidities was 1.00 (1.00-2.00). The mean of BM was $25.9 \pm 4.7 \mathrm{Kg} / \mathrm{m}^{2}$. Twenty-one of the patients were classified as active or passive smokers, thirty-five said they were former smokers and thirty-eight never smoked. Sixty-nine $(80,2 \%)$ out of the ninety-four patients in the study had at least one type of comorbidity (mean 1, 44 $\pm 1,04$ ). Eighty-three patients $(88.3 \%)$ showed a SARC-F score without signs suggestive of sarcopenia (0-5) and eleven patients $(11.7 \%$ ) showed suggestive to sarcopenia (6-10). In $\mathrm{HAQ}$, fifty-seven $(60.6 \%)$ patients had mild incapacity, thirty-five $(37.2 \%)$ had moderate incapacity, and two patients $(2.2 \%)$ had severe incapacity. Higher SARC-F scores were associated with greater number of comorbidities $(r=0.2 ; p=0.027)$, higher physical disability by HAQ $(r=0.5 ; p=0.000)$ and lower albumin levels $(r=$ $-0.3 ; p=0.048$ ). On other hand, SARC-F was not associated with time of diagnosis, C-reactive protein (CRP), erythrocyte sedimentation rate (ESR), creatine Phosphokinase (CPK), hemoglobin, hematocrit and creatinine.

Conclusion: SARC-F scores were associated with comorbidities, physical disability and lower albumin levels in systemic sclerosis patients. Considering that comorbidities, physical disability and the albumin deficit enhances the patient's muscle loss, SARC-F appears to be a good tool to screen sarcopenia risk factors in systemic sclerosis patients. Longitudinal studies are necessary to validate the SARC-F questionnaire in this population.

References:

[1] Hochberg MC et al. Sixth edit. (Elsevier, ed.). Philadelphia; 2015;

[2] Sakuma K et al. Pflügers Arch - Eur J Physiol. 2017;469(5-6):573-591.

[3] Caimmi C, et al. Clin Rheumatol. 2018;37(4):987-997.

Acknowledgments: We thank the Coordination for the Improvement of Higher Level Personnel (Coordenação de Aperfeiçoamento de Pessoal de Nível Superior-CAPES) institution, the Foundation for Research Support of the Rio Grande do Sul State (Fundação de Amparo à Pesquisa do Estado do Rio Grande do Sul-FAPERGS), the Research and Events Incentive Fund (Fundo de Incentivo à Pesquisa e Eventos-FIPE) of HCPA and Technological Development (Conselho Nacional de Desenvolvimento Científico e Tecnológico-CNPq).

Disclosure of Interests: Leonardo Santos: None declared, Rafaela Cavalheiro do Espírito Santo: None declared, Vanessa Hax: None declared, Rafael Mendonça da Silva Chakr: None declared, Ricardo Xavier Consultant of: AbbVie, Pfizer, Novartis, Janssen, Eli Lilly, Roche

DOI: 10.1136/annrheumdis-2020-eular.3800

\section{Other orphan diseases}

\section{OP0270 TRHEUMA REGISTRY EXPLORES CHARACTERISTICS AND SUITABLE DIAGNOSTIC AND THERAPEUTIC MANAGEMENT OF RHEUMATIC IMMUNE-RELATED ADVERSE EVENTS (IRAES)}

K. Benesova ${ }^{1}$, L. Diekmann ${ }^{1}$, H. M. Lorenz ${ }^{1}$, K. Jordan ${ }^{1}$, J. Leipe ${ }^{2} .{ }^{1}$ University Hospital Heidelberg, Department of Medicine V, Hematology, Oncology and Rheumatology, Heidelberg, Germany; ${ }^{2}$ University Hospital Mannheim, Division of Rheumatology, Department of Medicine V, Mannheim, Germany 